\title{
Литература:
}

1. Adamson Lynda G. Recreating the Past: a Guide to American and World Historical Fiction for Children and Young Adults. Westport; Connecticut: Greenwood Press, 1994. 494 p.

2. De Groot J. The Historical Novel (the New Critical Idiom). Abingdon: Routledge, 2009. 200 p.

3. Hamnett B. The Historical Novel in Nineteenth-Century Europe: Representations of Reality in History and Fiction. New York: Oxford University Press, 2011. 332 p.

4. Maxwell R. The Historical Novel in Europe, 1650-1950. New York: Cambridge University Press, 2009. 323 p.

5. Ungurianu D. Plotting History: the Russian Historical Novel in the Imperial Age. Madison: The University of Wisconsin Press, 2007. 335 p.

DOI https://doi.org/10.30525/978-9934-26-039-1-58

\section{«ФРАГМЕНТАЦІЯ» І «З'СДНАННЯ» ЯК ВАЖЛИВІ ЗАСОБИ НАРАТОЛОГІЧНОГО АНАЛІЗУ КЛАСИЧНОГО ДЕТЕКТИВУ}

\section{Перенчук О. 3.}

старший викладач кафедри української та іноземних мов Тернопільського національного технічного університету імені Івана Пулюя м. Тернопіль, Україна

Критиків детективної літератури Вікторіанської епохи тривалий час цікавили переважно тематичні питання, пов'язані з сюжетом. Тематичноорієнтована увага критиків була зосереджена на способі, яким представлені злочинці та їх злочини; критики аналізували персонажів, особливо видатних фігур детективів, як професіоналів, так і аматорів, починаючи від Августа Дюпена Едгара По і сержанта Кафф У. Коллінз до Шерлока Холмса Конан Дойла і Еркюля Пуаро А. Крісті. Від ранньої критики, такої як А.E. Murch's The Development of the Detective Novel та Ian Ousby's Bloodhounds of Heaven: The Detective in English Fiction from Godwin to Doyle до пізніших робіт, таких як Glenn Most та William Stowe's The Poetics of Murder: Detective Fiction and Literary Theory i Martin Priestman's Detective Fiction and Literature: The Figure on the Carpe, тематичні студії допомагають детективному наративу стати «узаконеною навчальною дисципліною». 
В своїх наукових працях ряд теоретиків твердять, що наратив $є$ не лише головним способом дізнатись, а й головним засобом організації знань та інформації. Говорячи саме про детективний наратив, ми будемо розрізняти терміни «інформація» та «знання» як дві різні незалежні складові процесу отримання знань. Перший апелює до фактів, які є достовірними або які можна встановити. «Знання» вважатимемо більш ретельним зібранням інформації, яка може бути неповною або суперечливою.

Для прикладу, той факт, що, як стало відомо, заплямлена нічна сорочка у «Місячному камені» У. Коллінза належить Френкліну Блейку, становив би «інформацію», яку потрібно пов'язати з іншою інформацією, якщо «знання» дійсної історії викрадення дорогоцінного каменю будуть належним чином трактовані.

Дана робота наводить докази того, що детективний наратив XIX ст. створює два важливі наративні ходи, названі «фрагментація» i «з'єднання». Ці наративні засоби мають істотне епістемологічне значення. На початку детектив надає фрагментовані, розірвані докази, а далі зв'язує ці докази у послідовну розповідь. Наративні стратегії «фрагментація» $\mathrm{i}$ «з'єднання» $є$ двома сторонами одного процесу, які працюють разом. Вони це роблять спочатку розбиваючи традиційні наративи ідентифікації, а потім ініціюючи не лише новий вид епістемологічного процесу, але й нові стосунки між нараторами i нарататорами.

Розглядаючи Вікторіанський детектив, Д.А.Міллер заявляє у своїй праці «Роман і Поліція», що класичний детектив формально базується на «гіпотезі, що будь-щзо може мати значення» [6, с. 45-55]. Іншими словами, вся фрагментована інформація в романі потенційно може вибудуватись у зв'язний наратив.

Патрік Брентлінгер виділив один з аспектів цього процесу, описуючи стосунки наратора і типового детективного сюжету у роботі «Що $\epsilon$ «сенсаційне» у сенсаційному романі?»: таємниця діє подібно до історії, яку наратор не хоче або забув розповісти; тепер детектив повинен «скласти частинки в єдине ціле». Брентлінгер пов'язує обмежене всезнайство наратора у детективному оповіданні з розірваним сюжетом, який потрібно «відновити». Науковець вважає, що наратор є обов'язково співучасником, коли, виявляється, що сюжет імітує «історію, яку наратор відмовляється» розповідати [3, с. 1-28].

У багатьох випадків читацька солідарність надалі підривається прийомом розповіді від кількох осіб (multiple narration), як це зробив Коллінз у «Жінці в білому». Такий стиль нарації не лише фрагментує 
події твору, надаючи можливість їх переповідати кільком дійовим особам, але робить їх несхожими, щоб читач міг їх порівнювати. Зокрема, в романі Бреддон «Таємниця Леді Одлі» розповідь ведеться всезнаючим наратором, але часто супроводжується репліками Роберта Одлі - можна сказати, персонажа, який мало пов'язаний з головними подіями в творі навколо Леді Одлі.

Пітер Томс у своїй праці «Detection and Its Designs: Narrative and Power in I-Century Detective Fiction» твердить, що «твори покладаються на авторитетних оповідачів, залежність, яка частково пояснює, чому детективна література (з її акцентом на процесі вирішення) не виникла до XIX ст.., коли особі детектива почали довіряти» [8, с. 44-65]. Томс не бере до уваги той факт, що, тоді як особа детектива набула довіри, самому наративу стали менше довіряти. Популярності набули фрагментовані наративи, складені з пропусків, в яких багато важливої інформації приховано від читача. Такий вид наративу не $є$ унікальним для детективних романів; примітно, те, що будь-який романний наратив $\epsilon$ більшою чи меншою мірою фрагментований, є головним принципом наративної теорії. Проте, що стосується детективної літератури, то тут має місце явище, яке Брентлінгер називає «розділенням (розпорошенням) наративної влади». Дане явище фундаментально змінює здатність читача покладатись на голос оповідача. Аналіз Донни Беннет у іiі праці «Тhе Detective Story: Towards a Definition of Genre» пропонує термін «confidentiality» для опису тієї міри, до якої читач може довіряти правдивості (достовірності) в романі. Її аналіз описує 5 рівнів довіри від 0 рівня (коли читач перебуває у повній темряві) до (майже) повної confidentiality. [1, с.250-257] Детективні романи все більше почали демонструвати повну відсутність «confidentiality». Однак, незважаючи на те, що така наративна практика маскує певні знання, потрібно визнати, що вона прокладає дорогу іншим, новим знанням. Якщо традиційні наративні моделі роз'єднують (розбивають, розкладають), їм ще й вдається «впустити ті знання, які реалістична література часто виключала». Метою даної роботи $є$ дослідити, якими $\epsilon$ ці знання і яким чином вони подаються в наративі.

Найпродуктивніше вивчення стосунків детективної літератури $\mathrm{i}$ наративної форми було започатковане структуралістами. Як свідчить сама назва цього напрямку критики, їх цікавив розгляд фундаментальних структур детективної літератури і вони його робили за допомогою наратологічного аналізу. Їх метою було формулювання загальної «граматики» детективного наративу; ця граматика, добута зі спільних 
структур сюжету, допомогла б пролити світло на основні риси «літературних законів», за якими вважається працюють всі наративи.

Ці «літературні закони» Цвєтан Тодоров назвав «поетикою» детективної літератури, термін, який він вжив для систематичної структури, яка організовує всю подібну літературу незважаючи на окремі відхилення менш важливих рис. Дві найважливіші праці, які вивчають і намагаються дати визначення цієї «поетики» - «Типологія детективної літератури» Цвєтана Тодорова і «Наративні структури у Флемінга» Умберто Еко [5; 9]. Структуралісти, як Тодоров і Еко, роблять цінний внесок у вивчення понять і термінів для опису стосунків між твором (story) i дискурсом ( discourse) у детективних наративах. Одне з таких важливих понять, запозичене у російських формалістів, це відмінність, яку роблять наратологи, між фабулою ( fabula or «histoire»or «story») i сюжетом ( sjuiet or «discourse» or «plotted narrative). Іншими словами, концептуальний поділ між sjuiet i fabula $\epsilon$ важливим для розуміння принципів «повтору», «перерозподілу» і «реконструкції», які досліджують наратологи.

Що стосується детективного роману, даний поділ особливо помічний, бо підтверджує той факт (який відзначає цілий ряд критиків), що у детективі розповідається не одна історія, а дві. Тодоров наголошує, що «таємниця», яка $\epsilon$ часто «злочином» у детективі «є, фактично, історією про відсутнє: її найточнішою рисою $є$ те, що вона не може бути негайно присутня у книзі». Він розрізняє відсутню історію «злочину» і присутню історію «розслідування», яка є проміжною історією, яку ми розуміємо як «сюжет». Ця остання історія - яка зосереджується на розслідуванні відсутньої історії - $\epsilon$, врешті-решт, про вирішальні пропуски у знаннях (наприклад, чого не знають читач і детектив) з прихованою обіцянкою, що ці пропуски будуть закриті або «з'єднані» фіналом твору. Це 3'єднання є, звичайно, двояке: воно охоплює не лише численні невідомі пропуски у фрагментованій, відсутній історії, але так само об'єднує історію злочину з історією розслідування.

\section{Література:}

1. Bennett, Donna. The Detective Story: Towards a Definition of Genre. PTL: A Journal for Descriptive Poetics and the Theory of Literature 4 (1979): 233- 66.

2. Braddon, Mary Elizabeth. Lady Audley's Secret. 1862. Ed. David Skilton. New York: Oxford University Press, 1987.

3. Brantlinger, Patrick. What is 'Sensational' About the Sensation Novel? Nineteenth-Century Fiction 37 (June 1982): 1-28. 
4. Collins, Wilkie. The Moonstone. 1868. Ed. Sandra Kemp. New York: Penguin, 1999.

5. Eco, Umberto. «Narrative Structures in Fleming.» The Role of the Reader: Evidence in England. Baltimore: Johns Hopkins University Press, 1992.

6. Miller, D.A. The Novel and the Police. Los Angeles: University of California Press, 1988, pp 222

7. Peterson, Audrey. Victorian Masters of Mystery: From Wilkie Collins to Conan Doyle. New York: Frederick Ungar, 1984.

8. Thoms, Peter. Detection and Its Designs: Narrative and Power in $19^{\text {th }}$-century Detective Fiction. Athens, Ohio: Ohio University Press, 1998. P. 44-65

9. Todorov, Tzvetan. The Typology of Detective Fiction. The Poetics of Prose. Trans. Richard Howard. Ithaca: Cornell University Press, 1977.

DOI https://doi.org/10.30525/978-9934-26-039-1-59

\title{
ОСОБЛИВОСТІ ПОЕЗІЇ М. ВІНГРАНОВСЬКОГО (ТРОПИ, ПОЕТИЧНИЙ СИНТАКСИС, ФОНІКА)
}

\author{
Погребенник І. Л. \\ кандидат філологічних наук, \\ викладач української мови і літератури \\ Чернівеиького вищого комериійного училища
}

Київського національного торговельно-економічного університету м. Чернівиі, Україна

М.Вінграновський - один із найвідоміших українських поетів XX ст., чия творчість набуває все більшого суспільного значення. Окремі елементи поетики творів М.Вінграновського досліджували А. Макарів, М. Ільницький, . Дзюба, Ю. Ковалів, Т. Салига, Ю. Сердюк, В. Моренець, І.Гришин-Грищук, Л.Талалай, Р.Дідула, Л. Старовойт. Однак спеціального системного дослідження поетики віршованих творів М. Вінграновського у діахронії досі немає, що й обумовлює актуальність теми.

Найчастіше у поетичній творчості М.Вінграновський звертається до порівняння та всіх його видів. Серед простих переважають індивідуально-авторські: «Як танський фарфор - все минає: Корою, снігом, рукавом...» [5, с. 5]. До розгорнутих порівнянь, або ж 